This is the peer-reviewed version of the article:

Džinović, V. The Multiple Self: Between Sociality and Dominance. Journal of Constructivist Psychology 2020, $O$ (0), 1-19. https://doi.org/10.1080/10720537.2020.1805063.

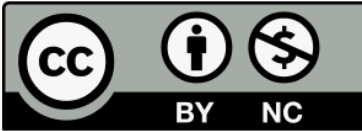

This work is licensed under the Creative Commons Attribution-NonCommercial 4.0 International license 


\title{
The Multiple Self: Between Sociality and Dominance
}

\author{
Vladimir Džinović \\ Institute for Educational Research, Belgrade, Serbia
}

\begin{abstract}
We begin from the current approaches to the multiple self - Bakhtin's concept of polyphony, Mair's community of self and Hermans' dialogical self theory. Polyphony assumes that the self consists of multiple different voices, which simultaneously exist and interact in complex dialogical relations. The metaphor of the community of self enables us to perceive how the individual, depending on a specific social context, can use different selves, as subsystems of constructs which are mutually incompatible. Dialogical self theory enriches the idea of the polyphonic self with the idea of the extended I, in which the voices of others appear as simultaneous external and internalized I-positions. Further on this paper proposes that the understanding of the multiple self is complemented by the implementation of the concepts of sociality and relations of domination. Then, a methodological approach is presented for the study of sociality and dominance in the multiple self. The paper also presents a case study of a successful student's community of self as an illustration of the implementation of this methodological approach. The case study shows that the student's community of selves is marked by tension between dominant voices and voices of resistance which always have the potential to change the balance of power, making the sense of self as a student both changeable and inconsistent. The other significant finding is that the role relationships which are established between some voices could serve to either establish or maintain the domination in the multiple self.
\end{abstract}

This work deals with Kelly's idea of sociality and its link with the power relations in the specific context of the multiple self. The goal which we set is a) to analyze sociality and dominance as processes characteristic of the multiple self, starting from polyphony (Bakhtin, 1929/1984), Mair's (1977) metaphor of the community of self, the dialogical self (Hermans \& Kempen, 1993) and Foucault's (1979) theory of power; b) to present a methodological approach to studying sociality and dominance in the multiple self. Firstly, we will introduce sociality, as both an interpersonal and intrapersonal phenomenon. In his theory, Kelly (1955) gives great significance to social relations, emphasizing that the predominant part of the system of constructs develops along with the anticipation of the constructions of others, as the most important events in the social world in which a person lives. In order to build close and intense relationships with another person, it is necessary to observe the world from the viewpoint of that other person and to anticipate what the other expects from us as their partner. As Kellyunderlined, to achieve harmonized and fruitful relations we cannot expect people to be similar in every way, but rather for them to understand things in the way in which others understand those things, i.e. to play a role in relationships with others. The activity of subsuming others' constructs should be reciprocal in order for partners to adjust to each other and to create joined activities. Of course, the role relationship does not just mean harmonized relations, or 'dancing to another's tune'. Furthermore, the expectations of others may be opposed more effectively when the personal meanings from which those expectations originate are understood (Kelly, 1969). We talk about team cooperation, which includes conflicts, confronting the expectations others have of us, as well as negotiations regarding the shared meanings of social endeavors. The role relationship presents the basis of constructivist ethics, 
as the principle by which we should organize our relationships as morally responsible persons (Procter, 2014; Stojnov, 1996).

Procter $(1981,1996,2014)$ points out the importance of construing relationships within the community to which we strive to belong and not only the mental processes of its individual members. Social relationships which include several individuals are characterized by complex patterns of interaction, ambiguous situations and polarities, thus making it necessary to conceptualize them as events which are on the level of interpersonal constructs, whether they refer to the construction of relationships between two persons or the construction of triads.

When we anticipate the processes of interpersonal construction 'we get out of our individual heads' and devise meanings which represent the result of active efforts to elaborate "our shared, mutual construct system" (Procter, 1996, p. 177). Interpersonal construing thus gains the meaning of spontaneous bodily joint action (Shotter, 1989, 1993), in which the participants mutually constitute the sense of what they build in the relationship, or in Shotter's terms, knowing from within. Knowing 'you' and knowing from within the relationship - knowing 'us' - represent the two key activities of construing the social world, which enable us to realize ourselves as individuals and to participate in moral order together with other people.

Sociality and relationality (Procter, 2014) are not just qualities of interpersonal relationships, but also of intrapersonal ones. The phenomena of mutual understanding, but also misunderstanding, objectivizing, conflict and the struggle for domination are also evident in the private, reflexive domain of the person if we perceive the self as polyphonic (Bakhtin, 1929/1984), a community (Mair, 1977), the "society of mind" (Hermans, 2002) or the dispersion of the subject in the multiple discursive positions of subjectivity (Foucault, 1972). Therefore in this paper we will examine sociality and dominance taking into consideration these most influential approaches to the multiple self.

\section{From the one to the many}

First we will briefly present the dominant ideas about self that come from the concept of centralized as opposed to multifaceted personhood (Sampson, 1985). Traditionally, the self is defined as the person's reflexive domain that she refers to as "I" (Stojnov, 2005). What is considered to be the self is the internal center of self-consciousness, selfknowledge and action, but also a unique collection of personal potentials and characteristics (Harr_e, 1998). It is, in other words, a particular psychological agent that represents an integrated wholeness and single personality consisted of distinctive traits, tendencies and abilities, as well as thoughts and feelings which are private and internal states (Geertz, 1983; Stojnov, 2005; Taylor, 1989). The emphasis on integration and completeness of the self is particularly visible in considerations of how it perceives itself as constant and different from other selves (Baumeister, 1986; Locke, 1690/1975; Stojnov, 2005). For example, Erikson $(1959,1994)$ points out that the internal integrative processes of the Ego are responsible for the creation of one's entire consistent identity out of numerous significant identifications. The idea of self-concept likewise relies on the assumption that an internal structure, like one of personality traits, provides the integration of personal experiences of self and opinions of significant others into a stable perception of self (Shavelson \& Bolus, 1982). McAdams (1985, 2001) also highlights that integrity is the distinctive characteristic of sense of self, as a narrative construction that organizes various elements of personal history and fragmented experiences of self into a coherent whole. Hence, predominant conceptions of self focus on qualities such as the existence of a stable center, personal continuity, unified subjective past and future, integration of diverse life experiences into a flexible whole, constitution within social relations that allows for a meaningful participation in social interaction, and personal sense of worth and purpose (Baumeister, 1986; Blasi, 1988). 
However, the world we live in contains a great number of values, ideologies and social contexts, often mutually incompatible. This means that there is a great number of potential ways to be, all of which are mutually incomparable dimensions of defining the sense of self (Baumeister, 1986). Under these circumstances, people are faced with diverse experiences and fragmented senses of self that are impossible to comprise a single monolithic personality system (Kelly, 1955). It would seem fair to replace the contemporary discourse on crisis of identity (Baumeister, 1986) with one of crisis of predominant concept of self as a centralized and totalitarian structure, which opens space for different models toward the idea of a decentralized self - "a pantheon of selves within a single body" (Sampson, 1985, p. 1210).

\section{Polyphony and self}

In this section we will introduce an approach that is most influential for the early development of the alternative idea of the multiple self. It conceives self as composed of different ideological or epistemological perspectives which appear in the form of voices and interact in the individual's consciousness. Mikhail Bakhtin (1929/1984) in his analysis of the characteristic poetics of Dostoevsky's polyphonic novel emphasizes that there is not only one perspective which shapes a person's experience of him/herself or the world, but many incommensurable 'voices', which dialogically pervade and supplement each other. The psychology of the hero of the polyphonic novel is marked by the coexistence and mutual influence of several confronting consciousnesses, which have their own standpoint and their own will, and not their synthesis into a singular stance of perception and action. As Bakhtin (Volo_sinov1, 1973) said, where consciousness begins is the place where social interaction should be sought, because individual consciousness is shaped in the process of social creation and the use of meanings, therefore in live dialogical exchange within organized human society. Conscious experience (therefore experience of self) represents a dialogical, not a monological, phenomenon. This means that each voice, understood as a whole experience or point of view, is deeply dialogized, and polemically directed toward other voices in relation to which the voice gains meaning, as a response to them, as agreeing with or opposing those other voices. The following analysis of Raskolnikov's dialogized interior monologue shows to what extent sociality and relationality shape the polyphonic self:

"In the beginning of the passage Raskolnikov actually re-creates Dounia's words with her evaluating and persuading intonations, and over her intonations he layers his own-ironic, indignant, precautionary; that is, in these words two voices are sounding simultaneouslyRaskolnikov's and Dounia's. In the subsequent words "It's all Rodya, precious Rodya, her firstborn!" etc. one can already hear the mother's voice with her intonations of love and tenderness, and at the same time there is Raskolnikov's voice with its intonations of bitter irony, indignation (at the gesture of sacrifice), and sorrowful reciprocal love. Further we hear in Raskolnikov's words both Sonya's voice and Marmeladov's voice" (Bakhtin, 1929/ 1984, p. 75).

Voices are constantly 'aware' of other voices, are saturated with them, and reproduce the meanings of other voices through the use of specific expressions and linguistic constructions.

This essentially transforms them, because they become ambiguous and incomprehensible outside the context of the dialogical encounter with other voices. The multiplicity of perspectives in the individual's experience is, however, a reflection of the polyphony of the social world, in which: “...planes were not stages but opposing camps, and the contradictory relationships among them were not the rising or descending course of an individual personality, but the condition of society" (Bakhtin, 1929/ 1984, p. 27). Therefore, 
multiplicity is fully understandable and the only possible condition of the self if we consider the complexity of social relations toward which the self is open. Our dialogues with others are constantly developing in social space and do not stop on the borders of the individual's consciousness, but deeply penetrate it, transforming it into an internal space of dialogue. This leads to the disappearance of the distinct border between the external and the internal, between the social stage on which different ideological positions merge and the individual consciousness in which the dialogue between different voices occurs.

\section{The metaphor of the community of self}

Although there are no indications that Mair (1977) was under Bakhtin's influence, he further developed the idea of the multiple self by introducing the fruitful metaphor of a person as a community of selves. Namely, we often witness ourselves talking to ourselves, we have internal dialogues, in which one part of us shows support and agrees with the other part or disputes it, criticizes it, disparages it or even rejects it. Also, we may find ourselves having contradictory feelings, desires and expectations, which create the feeling of personal fragmentation and discord. These experiences, familiar to everybody, may be perceived as if we were 'populated' by multiple personalities, which have separate construing processes and can form different relationships. The metaphor of the community of self allows connection of the ideas of unity and multiplicity, placing the person at the forefront, in a similar way to Stern (1938) did when describing a person as unitas multiplex - a unity of multiple different characteristics, tendencies, feelings, choices, and directions.

Mair emphasizes that a person can, through different selves, explore and experience the world from many diverse perspectives, without the 'pressure' that all those streams of action have to be mutually coherent. In his Fragmentation Corollary, Kelly (1955) anticipates that a person can successively use different and mutually incompatible subsystems of construction. The reason for such fragmentation is that construing develops in social interaction, where a person anticipates the world through dialogue with others and not in isolation in his/her own mind. Namely, different relationships confront a person with various experiences, which are not possible to construe on the basis of one consistent system of anticipations alone, because issues which should be constructed in some relationships may be completely different to those which should be constructed in others. We develop more streams of anticipations in a process which, according to Vygotsky (1978), includes the mechanism of the internalization of diverse communicational practices we are immersed in. The internalization of social practices and fragmentation enable us to gain a better understanding of the multiple self. The different selves within a community could be viewed as subsystems which develop in specific social contexts and enable the individual to develop diverse and often contradictory roles.

When describing the dynamics in the community of selves, Mair uses terms which are usually used to describe social dynamics. Hence, for instance, when describing forms of organizing inside the multiple self, he talks about teams, camps, and factions. In his analysis of the relationships between the selves, he talks about the tactics which some selves use in relations with others, about those selves which are the most powerful, controlling or controlled by other selves, autocratic or subordinate, at the center of attention on the stage or less visible. Mair also talks about the fact that communication between selves could be absent, that some selves or groups do not want to recognize the existence of other ones, that some selves could intimidate others, present a threat to others' stance, that some selves are prepared to recognize the standpoints of the other members of the community and to participate in joint actions with other selves or that some selves are in balance with their opposite selves. In other words, the metaphor of the community of self enables the understanding of the individual's personal functioning with the help of constructs which are traditionally applied to politics, social groups and working 
organizations (Mair, 1977). In the same way, Mair uses Kelly's Organization, Choice, Range, Modulation and Fragmentation Corollaries as well as diagnostic constructs superordinate versus subordinate, regnant, core versus peripheral and comprehensive versus incidental 2 in order to explain the processes and strategies of organizing and managing the community of self.

Just like with Bakhtin, the most significant consequence of Mair's analogy in understanding interpersonal and intrapersonal relationships is the problematization of the deeply rooted differentiation between the internal and external as well as between the self and others. The aforementioned terms do not refer to specific places or entities, but assume constructs which have different meanings for different people and through which events may be mapped in very different ways. Thus, various 'external' events could be constructed as belonging to the self, in contrast to other events which are constructed as other, indicating that neither the self nor the other are inherent characteristics of things, but are determined by their relationships with each other. The other in that case could be either a person or some 'internal' self (self A), whom we approach from the point of some other self (self B) for whom self A is 'you'. In other words, a person can take on the position of another person, which in that case temporarily becomes part of the self, as the perspective from which the person perceives things and acts. In that way a necessary condition is created for the establishment of the role relationship within the community of selves.

\section{The dialogical self}

The polyphonic and dialogical position in psychology has been most elaborated by Hermans and his associates (Hermans \& Hermans-Konopka, 2010), who determine the self as "the dynamic multiplicity of the I-positions or voices in the landscape of the mind" (p. 31). Hermans describes the dynamics within the dialogical self as the movement of I between different positions, 'giving it a voice' and thus establishing dialogue between those voices. These positions are autonomous centers of activity, with their own stories, aspirations and emotions, which could be mutually contradictory (Hermans, 1996a). Such multiplicity reflects discontinuity within the self, because the different I-positions are in disharmony and mutually opposing. However, this polyphony represents the conditions and way of establishing unity within the self, because giving voice to different and mutually conflicting I-positions facilitates dialogical exchange, through which the coherent I is developed (Hermans, 2003). This means that the experience of self is some kind of consensus derived from a complex negotiating process between the I-positions.

What is particularly significant is that this theory takes into consideration the hypothesis on adopting function of the self (James, 1890) in order to develop the concept of the extended self. It implies that there is no distinct border between the self and others, i.e. that other persons are included in the dialogical polyphony as simultaneous external

positions and internalized voices (Hermans, 1996a). That in turn means that others are present in the self as objects with person-like characteristics and as persons with other perspectives, with whom we establish dialogical relationships. By approaching internalized others as separate and autonomous views on the world, we recognize and accept otherness as an important determinant of our sense of self and become capable of cognizing ourselves in relationships with others (Hermans, 2003). Hermans thus moves closer to Gergen's (1991, 2009) standpoint, which views the self as a multitude of socially based potentials for multi-being, which arises through the process of social saturation, whereby the self is 'populated' with the partial identities or characters of others. Of course, we should bear in mind Raskin's warning that we cannot simply take others' constructions: “...we merely devise constructions of the other person's constructs in a way that feels to both them and us as if we have replicated how they construe events" (Raskin, 2016, p. 40). 


\section{The multiple self and sociality}

The theoretical standpoints we have so far discussed suggest that the interweaving and permeation of different perspectives take place in the multiple self, which leads to theassumption that sociality is one of the concepts that we need to use to understand the creation of the sense of self as an internalized joint social enterprise. According to Bakhtin, voices are open to the epistemological positions of other voices and dialogically respond to them by agreement or questioning. Although he does not use the term sociality, Bakhtin seems to point precisely to this phenomenon in the field of linguistic practice, describing the dialectic presence of one voice in other voices. In dialogical self theory the sense of self is conceived as: "...a form of social exploration and discovery as part of an unfinished dialogue, both external with the actual other and internal with the imagined other" (Hermans, 2003, p. 104). The described process of the extension of the self represents an additional elaboration of the idea about role relationships. It points out the need for the others with whom we strive to establish a role relationship to 'populate' our reflexive space in the epistemological sense, in order to be able to perceive the world from a different perspective. Also, Mair underlined that the use of the term community should indicate the terms communion and fellowship, which depict a deeper connection and joined action within the multiple self as a desirable state. He concludes that complex interactions within the community of self may lead to a pattern of dedication to mutual interests and goals, in the way that activities in the community take on the form of a team game. In other words, one perspective could recognize another perspective in the multiple self and could attempt to match its processes and actions with that other perspective, changing its appearance by subsuming the expectations of the other perspective or opposing those expectations and striving to negotiate with it. In the case study of a student's community of self, specific examples of the establishment of role relationships between different "voices" will be illustrated.

\section{Polyphony and power}

So far, we have considered how sociality can be applied as a concept for understanding intrapersonal dynamics. In this section, it remains to consider how power, as an important aspect of interpersonal relationships, is reflected in relationships in a multiple self. An important addition to Bakhtin's concept of polyphony is the thesis that dialogue includes inequality of power, opposing relations, dominance and moral conflicts as characteristics of the polyphonic self (Hermans, 2003; Hermans \& Hermans-Konopka, 2010; Raggatt, 2000). Namely, Bakhtin (1929/1984) talks about polyphony as a community in which all voices are heard at the same time, as equal standpoints. Bakhtin uses such terms as the struggle between voices, confrontation, and dialogical opposition, claiming that the 'dominant ideology' attempts to stabilize social meanings which are in constant turmoil because of the dialogical struggle for the right to interpret reality between confronting social forces (Volo_sinov, 1973). However, he fails to emphasize that inequalities in power are essential features of the social dynamics which includes the struggle for dominance. Polyphony and dialogue do not exclude inequality in power, nor do they lead to the overcoming of the power relation. On the contrary, asymmetrical power characterizes each dialogical situation, because any exchange between positions implies that a certain position has initiative and manages to introduce dialogical themes and their interpretation to a greater extent than other positions (Hermans, 2003).

But more than that, power relations represent the constituents of subjectivity, and not a communicational epiphenomenon or a side effect that should be removed in order to achieve an assumed consensual sense of self. The standpoint that allows us to better understand the role 
of power in shaping the experience of self is Foucault's (1979) theory of power. First, it connects social relations of power with subjectivity as dispersed in multiple discursive positions. Second, Foucault's theory suggests that power relations are based on treating subjects as those who have their own perspectives as well as agency, thus allowing the connection of the concepts of multiple self, sociality and power.

Foucault (1979) defines power as a strategic relation of power, which relies on immanent inequalities and resistances in social relations in order to manage the individuals' activities. Such inequalities may be legal, economic, political, educational, or pertaining to health, and lead to social confrontation, on the basis of which relations of domination

and subordination are established as manifestations of differences in power. Power is, therefore, relational and exists only in social action, it is not possessed, does not gain or lose, and does not represent an individual characteristic. In another place, Foucault (1982) defines power as undertaking action over the actions of others, governing the field of the possible action of others. Power is exercised by means of surveillance and examination, as mechanisms by which full visibility of the subjected individuals is achieved. Surveillance is continuously implemented in the network of power relations, which means that each position is supervisory, and also subordinate, supervised by some other position. In examination the individual is involved in various practices where he/she is forced to talk about him/herself, to confess details from his/her life in front of instances of normalized views such as parents, teachers and doctors. Testifying to his/her thoughts, forbidden desires, and 'perverted' intentions, the individual participates in the ritual of the production of the truth about him/herself, which is widely spread in western societies and deeply rooted in previous practices of Christian confession (Foucault, 1979, 1995).

The particularly significant consequence of confessional power is the production of knowledge about the subjects, through which they shape their sense of self and develop as specific types of people. When talking about the subject, Foucault (1972) implies the multiple positions of subjectivities created in discursive practice, which may temporarily occupy individual bodies. Unity of consciousness, perception and action, as forms of the traditional subject, here give way to the dispersion of the subject into numerous partial positions of giving accounts, thought and cognition, which could be ascribed to an embodied individual. The entities through which individuals describe themselves, such as consciousness, self, personality and identity, appear in the field of knowledge as objects of historically contextualized discourses which shape the body, by 'implanting' the psychological subject in it. In this way, control is established over individuals as they are offered a field of diverse subjectivities.

One of the implications of Foucault's theory of power is that the multiple self may be viewed as a complex 'stage' on which multiple positions of subjectivities struggle for the possibility to impose a certain version of self-knowledge. The struggle for domination represents both the inherent state of the multiple self and the precondition for the construction of the complex sense of self, because only in certain strategic situations, which are characterized by the domination of some forms of subjectivity, can a narrative about the self emerge. In other words, the awareness of who I am originates from the struggle between different instances of subjectivity for legitimacy to 'speak', in which one of the instances (or groups) takes over the position of power, thus creating a temporary and socially contextualized constellation of power. Also, the struggle for domination cannot be understood without resistance, as the potential of the opposing side to participate in the game of power and continually 'threaten' to carry out a reversal in the power relations. This means that the predominant position of a given voice is determined in relation to the other voices which take on the position of subordinate or resistant voices, just as the meanings which those voices articulate are determined in the dialectical tensions between the oppositions in the multiple self. This tension, resulting from the constant 
presence of alternative subjectivities, is what makes the multiple self incoherent, ambiguous and constantly open to the further distribution of subject into voices of culture, the economic and political systems, and those of research practice.

The second important implication refers to the recognition that power rests on the role relationship, and is not its opposite. As previously stated, power is analytical and to a great extent psychologized, it carefully examines the subjects of its action and treats them as agents with developed individualized mental lives. Foucault distinctively and categorically points out that power is exercised through practice which in constructivist terms we would describe as subsuming:

"... this form of power cannot be exercised without knowing the inside of people's minds, without exploring their souls, without making them reveal their innermost secrets. It implies a knowledge of the conscience and an ability to direct it" (Foucault, 1982, p. 214).

It is interesting that Kelly, in a similar way, links the governing of others with sociality. Talking about the role of the leader, he says: "By 'understanding' we do not mean that he necessarily holds the common viewpoint, but rather that he has a way of looking at his colleagues' ideas that makes sense and enables him to predict their behavior" (Kelly, 1955, p. 101). Power which represents action over the actions of others relies on the construing of the processes of construction of those whose activities are arranged. What is needed is to anticipate the acts of others, their intentions, desires and choices in order to prepare tactics to ensure that the field of possibilities for the movement of individuals is placed in the service of their productivity. To make this possible, power has to have a clear understanding of the logic which leads the individual, the alternatives which he/she sees as open to him/her, to anticipate the identities which he/she strives to affirm, and most importantly to observe him/her as somebody who could make choices between many alternative discourses of subjectivity. In other words, power demands that individuals participate in relations of dominance as persons:

“... a power relationship can only be articulated on the basis of two elements which are each indispensable if it is really to be a power relationship: that 'the other' (the one over whom power is exercised) be thoroughly recognized and maintained to the very end as a person who acts; and that, faced with a relationship of power, a whole field of responses, reactions, results, and possible inventions may open up" (Foucault, 1982, p. 220).

In the power relation, therefore, the instance of surveillance assumes the same position toward the subject as a psychotherapist, a socially engaged researcher, a progressive pedagog or a social activist, but the outcomes of such treatment are completely different. Power, which is mainly reflected in the institutional practices, uses such an approach in order to strengthen the order of obedience/usability and to totalize its effect through further individualization. The other actors use the role relationship to introduce individual resistance to the imposed constructions of identity or to connect with others and organize joined action which could lead to more favorable roles in the network of interpersonal relations.

\section{An illustration of sociality and dominance in the community of self: case study}

We will now present the methodological approach to research into sociality and power relations in the multiple self. We will also present a case study as an illustration of the implementation of the proposed methodological approach. The case study method is applied as a general approach which enabled the creation of a collage of research strategies for data 
collection and analysis in accordance with the starting theoretical standpoint. Such an approach corresponds to the contemporary moment in qualitative research, which implies that the researcher uses various methods, techniques and empirical materials at hand and, as required, invents new tools in order to gain desirable and useful effects (Denzin \& Lincoln, 2005; Kincheloe, 2001, 2005). The other reason for the choice of a case study is that it enabled the presentation of specific examples of the student's community of selves, through which the general theoretical assumptions about the researched phenomena are linked to the specificities of its manifestation in individual cases (Willig, 2008).

\section{Data collection and analysis}

The case study presented in this paper is derived from a broad qualitative study about life priorities and sense of self in the context of the school success of secondary school students, in which eleven successful and fourteen unsuccessful students from a secondary vocational school in Belgrade participated. The participants were students who, after participation in the first phase of the study (focus group), voluntarily agreed to talk further with the researchers about how they see themselves in the context of school success. Two criteria were used for the selections of the participants in the research: success at the end of the first semester of the 2017/18 school year3 and the students' voluntary agreement to participate in the research. As an illustration of the relations of cooperation, conflict and the struggle for domination in the multiple sense of self as a student, the community of self of a successful female student will be presented.

In the data collection process semi-structured interviews about the students' polyphonic identity were conducted. The agenda and procedure for the interviews were designed in accordance with theoretical ideas of polyphony, the community of self and power relations so as to enable the mapping of the multiple voices which constitute a person's sense of self, as well as a description of the relationships between those voices, with a particular focus on domination, cooperation and conflict. The interviews involved the following steps: 1) the participants firstly declared whether they saw themselves as successful or unsuccessful students; 2) then they were encouraged to recognize in themselves different ways of thinking about their school success, different ways in which they perceived their personal experiences of school success; 3 ) leading from the standpoint of polyphony, the researchers encouraged the students to perceive those various viewpoints as metaphoric voices, which could be in different mutual relationships; 4) then followed the elicitation of voices and their graphic presentation, whereby the students named the voices and wrote down short narratives which reflected the position of each one; 5) further on, the participants were encouraged to "recognize" in some of their thoughts and messages the voices of significant others, such as those of their parents, teachers, peers, and similar, and to complement their communities of selves with them; 6) finally, the participants described the relationships between the elicited voices taking into consideration the dimensions of domination versus marginalization and cooperation versus conflict. The laddering technique (Hinkle, 1965; Walker \& Crittenden, 2012) was used in the interviews to map personal constructs as semantic bipolar dimensions through which the participants conceptualized opposing experiences regarding school success. The interviews lasted around one hour and audio recordings were made with the participants' approval.

For the data analysis within the case study a deductive approach to thematic analysis (Braun \& Clarke, 2006; Mayring, 2000) and Foucault's genealogical analysis (Dreyfus \& Rabinow, 1982; Foucault, 1979) were used. Pursuant to the principles of thematic deductive analysis, the data from the interviews were analyzed through categories based on Kelly's theoretical model of role relations, Mair's (1977) community of self metaphor, Bakhtin's (1929/1984) polyphony and Foucault's analytics of power (Dreyfus \& Rabinow, 1982; 
Foucault, 1979). Analysis was carried out into which voices or selves make up the community of self of successful and unsuccessful students and we named that category the Structure. We also analyzed the relationships within the students' community of self, with a particular focus on the establishment of the role relationship, cooperation, conflict and domination. We named this category the Dynamics, and within it we created two sub-categories for the sake of a clearer analysis of the relations between the selves: Cooperation versus conflict and Domination versus subjection. For the additional data analysis genealogical analysis was used, in the aspect which refers to the analytics of power, because that enabled the use of the terms struggle for dominance, strategic situation, maneuver and resistance (Author, 2010; Foucault, 1977, 1979, 1982). Those were suitable interpretative means to gain a better understanding of the power relation in the multiple self and as such represent an extension of the theoretical category of Dominance versus subjection.

The analytic approach included the separation of the transcript parts which corresponded to the theoretical categories and their presentation in narrative form, with quotes from the students' statements, thus providing authenticity. This included several iterations of comparison of the categories and research narrative descriptions with raw material, in order to stay as close as possible to the original data. Study case:

"I like to study. That is, probably, strange now for you"

Milica is a student in the third grade of the secondary medical school in Belgrade. She completed the first semester of the current school year with an excellent average grade. She moved to Belgrade in order to attend secondary school and lives in a student residence. She perceives herself as 'a good pupil'.

\section{The voices}

Her community of student self consists of the following voices: The real me, The lazy me, The angry me, The voice of the peers, The parents' voice, The grandparents' voice and The neighbors' voice. Milica firstly sets aside The real me, which shows that this voice is the most present, that she identifies with it the most and, in her own words: "That is me, just the real me." The real me talks about the importance of being in accordance with the picture important others have of her:

Milica: "[It's important] to satisfy everybody, I try to satisfy my teachers ... I have to balance both family and teachers".

Interviewer: "Why is that important?"

Milica: "I want to make an impression on them, I want them to see that I make an effort and I want to achieve some success."

The role which The real me is trying to realize and maintain may be understood by observing the rhetoric of the voices which come from her parents, grandparents and neighbors. The parents' voice advocates the position: “... should study, should be educated... so in the end you'll complete school and have your own money". The grandparents'

voice also provides narrative about the importance of education, but also about the transgenerational achievement of educational aspirations: "They expect me to be good at school, as though I study for them too, I'll do what they were unable to do". The neighbors' voice is in agreement with the previous two voices: "They tell me that it's good to study, that I'll need that 
later in life". It is evident that The real me subsumes the standpoints of the aforementioned voices, which are influential and have authority, and on that basis constructs her own role as someone who is attempting to realize those standpoints by means of different maneuvers within the community of self. It is particularly visible that The real me establishes a role relation with The grandparents' voice, because she subsumes its construction particularly in that part which refers to the expectations of her as a student.

\section{The antagonism between The real me and The voice of the peers}

Therefore, the key dynamic through which it is possible to understand the construction of Milica's community of student self is represented by the struggle for predominance between The real me on one side and The voice of the peers and The angry me on the other. The voice which represents one of the key opponents to The real me in her attempt to achieve the desirable perception of herself as successful in school is The voice of the peers. The meaning of The real me is to a great extent determined by her relationship with this voice of resistance. The messages which The voice of the peers sends are: "We don't have to study..." and "If they [peers] don't study, I shouldn't study either. It's like we're in it together, so we should get away with it more easily". The student's statements make it possible to gain insight into how The real me interprets those messages: "As for my peers I can tell you straight away that nobody studies now, that it's just so laid-back and relaxed in school. So if anyone studies, that's the big surprise". Therefore, The real me recognizes a threat to its position in The voice of the peers and in the dialogical exchange with it responds with the following arguments: "I think, that's not OK for me, I wouldn't do that, I should finish school, and afterwards I should go further. You're really good friends to me, but you don't have much influence on me not to study" and "You should study because that pays off in the end. To finish some school is also important, and not to remain uneducated... Today when you see somebody with no school who's uneducated, it's also very ugly, but when you see such a handsome, educated man, it's better than seeing an uneducated one". In other words, although the point of view of The voice of the peers can be "heard" in her narrative ("It's like we're in it together, so we should get away with it more easily"), The real me dialogically replies to that point of view by placing her own position at the opposite pole. We can assume that openness to the opposing viewpoint results in a threat, and then to a dialogical strategy whereby such a viewpoint is delegitimized, as something that is not just different but also unacceptable. Thus, The real me alludes to arguments which have starting points in the perspectives of authoritative voices (parents and grandparents). In that way this voice establishes domination over The voice of the peers and ensures that Milica's activities lead to investing effort in educational achievement: "I study, get good grades, and with that show that this [The real me] is dominant. To them [The voice of the peers] I prove that I will not be like them, will not get bad [grades] like them".

\section{The real me against The angry me and The lazy me}

The voices to which The real me also attempts to defend the viewpoints which she shares with The parents' voice, The grandparents' voice and The neighbors' voice are those of The lazy me and The angry me. Namely, at moments when Milica feels worn out and tired, after a period of intensive studying, The lazy me appears: "When there's no chance of my studying, and that's rare, you know, when I don't have the strength, or desire, when I can't be bothered [to study] ... When I really put it [studying] off." The argument The lazy me uses to account for her attitude toward studying suggests the possibility of postponing school obligations: "There's time, I'll do it tomorrow". Also, one of the ways in which The lazy me attempts to 
undermine the position of power of The real me is to use the narrative of the dangers of being overburdened:

Milica: "Sometimes I spend the whole weekend studying and then that voice appears telling me not to study so much. Sometimes I listen to it, sometimes I don't."

Interviewer: "What does it say, why shouldn't you study so much?"

Milica: "Because it's not good to exaggerate in anything."

This narrative about studying too much as the danger of 'deviating', however, originates from The parents' voice: "They support me, but sometimes they also think that I overdo it. They also think that sometimes I should have a little rest and not study all the time". Hence, in this situation it is evident how The lazy me relies on the argumentation of the influential voice, in order to strengthen its own position.

In comparison with The lazy me, with the position: "And there are times when I really don't have the will to study", The angry me represents a greater challenge to The real me in the arena of the community of student self. In Milica's own words, this voice of resistance: "Sometimes really influences The real me and then she gives up and then she doesn't study, sometimes I really can't study for ten days". As Milica says, when The angry me dominates, the need arises to: "... go on the computer, watch films". However, Milica emphasizes that the situations in which The angry me achieves influence: “... don't happen often" and "... must not happen, because I'm in the third year [of secondary school]". In most cases The real me manages to delegitimize The angry me: "With that will to be successful, because I want to have excellent grades, with some desire and persistence I defeat that Angry me". In their opposite relation, the aforementioned voices construct the axis, which we could name: "I like to study, I want to be successful - I don't have the will to study, I want to be on the computer and watch films". This is an example of positioning on the group construct (Procter, 1996) or the dialogical positioning of I-positions on the opposite poles of constructs (Hermans, 1996b). We propose to name it the conversational construct (Author, 2014a, 2014b), as the semantic dimension on whose poles the opposed arguments of the participants in the dialogue within the multiple self are placed.

The angry me also takes on a different relationship toward the position of The parents' voice in an attempt to challenge its narrative about the importance of studying and education: "I'd really oppose that, I'd have a lot to say about that", and that is: "I don't like to study, I don't want to study after all, I don't want to finish [this school]". Namely, The angry me brings the very value of studying and education into question, in contrast to The lazy me, who values education, but believes that studying should be postponed. However, according to Milica's statements, in everyday life a merging of those two positions of resistance occurs, the outcome of which might be that extracurricular activities and content are given priority. In such a strategic situation The real me successfully plays her role and establishes domination over The angry me and The lazy me with the arguments: "Then again, I know that I can't, they are my parents and then, of course, I have to do what they say, I have to study".

\section{The role relations and the struggle for legitimacy}

In the struggle for predominance over the perspective represented by The angry me, The real me relies on support from The parents' voice and The grandparents' voice: “... who tell me that I shouldn't give up and that wakes me up and I start and keep going to the end", as well as The neighbors' voice: "When there's a really bad situation at school, they encourage me". To what extent The real me relies on the subsuming of the expectations and messages which 
come from The grandparents' voice in the struggle for the legitimacy of her perspective the student herself testifies. She states that she felt a responsibility to enroll in medical school because that was her grandmother's and grandfather's wish: "I didn't really like medical school, to tell you the truth, and in the fifth grade my grandfather died and the doctors couldn't do anything for him... They [grandmother and grandfather] inspired me because they talked about schooling all the time, that I should complete that because of my parents, for myself and then, somehow, that desire to go to medical school was awakened and, because of them and their desire, to complete that. That is the best way The real me won [over The angry me]".

We also notice that the other voices do not subsume The angry me and attempt to present her needs and expectations as a threat to academic achievement. The very fact that this voice is positioned as angry brings its legitimacy into question, and therefore in the community of selves there is no understanding for what The angry me is trying to achieve, what is important for her and which potentials for development she carries. On the other side, although The angry me bears the standpoints of The real me, The parents' voice and The grandparents' voice in mind, she represent the most important voice of resistance to those positions. In other words, despite participating in the polyphony, The angry me chooses to stay outside the role relations with the other voices, which would be the condition to accept the authority of The parents' voice and The grandparents' voice in the complex dialogical game within the community of self, and thus ensure the right to be heard of her perspective. Therefore, in the rare moments The angry me dominates, Milica faces dislodgement from the core role of somebody who strives to satisfy her parents and grandparents and to be a successful in school. The Real me uses the very fact that she is in a role relation with The parents' voice and The grandparents' voice to prevail in the dialogical struggle with the voices of resistance. However, Milica mentions that the struggle which The real me has with counter-voices in order to persist in studying and achievement is 'hard' and that in future she will need new alliances: "She is making an effort, but she needs more and more help".

\section{Conclusions}

The most important conclusion relates to the need to broaden understanding of the dynamics within the community of self with those constructs which refer to sociality, relationality and domination. Just like in the case of the hero from Dostoevsky's novels, in the presented community of student self, the voices are 'aware' of other voices, dialogically enter the viewpoints of other voices and, in response to them, create their own positions, thus constituting inter-subjectivity as a characteristic of the multiple self. This reflecting of other perspectives in our own, with which we always have unfinished dialogue, represents the precondition for the establishment of the role relationship within a community, which is one of the significant conclusions of our work. This is also visible in the presented case study of the community of voices. Namely, The real me, The lazy me and The angry me construct their own perspectives as a dialogical response to the voices of the parents, grandparents and neighbors, either as agreement with those influential voices or as resistance and taking up opposite positions toward them. In addition, the perspectives of parents, grandparents and neighbors are also directly present in the dialogues between The real me, The lazy me and The angry me, which can be seen in the fact that the arguments which The real me uses in her confrontation with The lazy me and The angry me refer to viewpoints about the importance of education. In the same way, despite subsuming the position of The voice of the peers, The real me strengthens its position on the opposite pole, in which the narratives of parents, grandparents and neighbors about the importance of education for success in life are again 'heard'. On the other side, the role relation with The lazy me and The angry me is missing, and because of that their perspectives are observed from 'outside' and dismissed as a threat. 
However, polyphony and sociality should be observed in the context of the struggle for domination in the community of self. The presented case study shows how the confrontation between voices is the basis on which sense of self as a successful or unsuccessful student is constituted. The voices compete with each other, 'working out' the tactics and maneuvers they will use to ensure the legitimacy and plausibility of their perspectives and thus take over the dominant position in relation to the other voices. On the other side, there is the constant tendency of the voices of resistance to usurp the existing order of power and affirm alternative positions of subjectivities. In that sense, the community of self may also be conceived in terms of a strategic situation, which implies the temporary and dynamic relation of power between different voices. It is temporary, because it refers to the momentary order of power on the 'stage' of the confronting or boosting of different perspectives, which provides some of them with the legitimacy and power to impose their arguments in the polyphonic sense of self. Dynamicity implies that there is always confrontation between domination and instances of resistance, which creates the possibility of a reversal and usurpation of power, which would lead to a change in the power relations.

When we take polyphony, sociality and domination into consideration, another of this study's important conclusions is that polyphony and sociality do not represent the path toward overcoming power in interpersonal or intrapersonal relations. Namely, it was shown that the role relation is not only the way to build team relations, but also the way to ensure the dominance and legitimacy of one's own perspective. We saw in the example of Milica's community of student self how The real me successfully maneuvers in complex situations involving the presence of confronting tendencies related to studying and prevails particularly thanks to the 'ability' to subsume expectations from The parents' voice and The grandparents' voice. Of course, the question could be posed as to the cost of such a role relation, which relates to burnout, but also to the closing down of certain alternatives which would be more Milica's. The angry me 'speaks out' about it in the rare situations when she gets the chance to confront The parents' voice and The grandparents' voice, telling them that medical school was not her choice. That means that sociality could serve to create communion, but also to exert power, ensuring that a given perspective maintains the dominant position.

Finally, another significant conclusion concerns the issue of coherency in the multiple self. Relations of domination imply confronting different interests, desires and perspectives, and constant 'tension' which originates from the struggle between confronting tendencies for temporary predominance in the landscape of the self, which often produces cacophony instead of harmony in this multiplicity. From the presented case study it can be seen how the sense of self is fragmented into several disparate subjectivities, whose viewpoints are mutually incompatible and far from constructing a 'polished' narrative. Taking that into consideration, the stability of self-understanding and acting could be ascribed to the temporary dominance of one perspective, which gains the right to impose a certain sense of self, rather than harmonious merging of diverse perspectives and elements into a wholeness, as the advocates of some theoretical positions attempt to show (Habermas \& Bluck, 2000; McAdams, 2001, 2006).

\section{Notes}

1. Bakhtin published some of his works under the name of his closest friend Volo_sinov. This was not known until 1973, when it was published by the Soviet linguist Vja_ceslav Vsevolodovi_c Ivanov, who reached this information in conversation with the Bakhtin himself. 2. Superordinate constructs are higher in the hierarchy in relation to subordinate constructs and include them as elements in their contexts. Regnant constructs assign their elements to a category on an all or none basis. Core constructs maintain the sense of life meaning, the most 
important values and identity while peripheral constructs represent more concrete manifestations of the core constructs, which are easier to replace. Comprehensive constructs subsume a wide variety of events as opposed to incidental constructs, which subsume a narrow variety of events.

3. The selection criterion for unsuccessful students was that they had unsatisfactory marks for two or more subjects, while the successful participants had excellent grades.

\section{References}

Bakhtin, M. (1929/1984). Problems of Dostoevsky's poetics. University of Minnesota Press. Baumeister, R. F. (1986). Identity: Cultural change and the struggle for self. Oxford University Press.

Blasi, A. (1988). Identity and the development of the self. In D. Lapsley \& F. C. Power (Eds.), Self, ego and identity (pp. 226-242). Springer-Verlag.

Braun, V., \& Clarke, V. (2006). Using thematic analysis in psychology. Qualitative Research in Psychology, 3(2), 77-101. https://doi.org/10.1191/1478088706qp063oa

Denzin, N., \& Lincoln, Y. (2005). Introduction: The dicipline and practice of qualitative research. In N. Denzin and Y. Lincoln (Eds.), The SAGE handbook of qualitative research (3rd ed., pp. 1-32). SAGE Publications.

Dreyfus, H. L., \& Rabinow, P. (1982). Michel Foucault: Beyond structuralism and hermeneutics. Harvester Wheatsheaf.

Džinović, V. (2010). Poslu_sno_s_cu do znanja [Obedience to knowledge]. Belgrade: Institute for Educational Research.

Džinović,V. (2014a). Konstruisanje promene: profesionalni razvoj nastavnika osnovnih i srednjih_skola [Construing change: Professional development of teachers]. [Doctoral dissertation,University of Belgrade]. University Theses and Dissertations Archive. http://nardus.mpn.gov.rs/handle/123456789/5031

Džinović,V. (2014b, June 20-23). A rethorical approach to personal constructs[Paper presentation]. The European Personal Construct Association 12th Biennial Conference Refresh your constructs!: Constructive alternativism in education, psychological care and democracy, Brno : Department of Social Education, Faculty of Education, Masaryk University, Czech Republic.

Erikson, E. H. (1959). Identity and the life cycle: Selected Papers. International Universities Press.

Erikson, E. H. (1994). Identity, youth and crisis. W. W. Norton \& Company, Inc.

Foucault, M. (1972). The archeology of knowledge. Tavistock Publications.

Foucault, M. (1977). Nietzsche, genealogy, history. In D. F. Bouchard (Ed.), Language, countermemory, practice: Selected essays and interviews (pp. 139-164). Cornell University Press. 
Foucault, M. (1979). The history of sexuality: Volume I: An introduction. Pantheon Books. https://doi.org/10.1086/ahr/84.4.1020.

Foucault, M. (1982). Afterword: The subject and power. In H. L. Dreyfus \& P. Rabinow (Eds.), Michel Foucault: Beyond structuralism and hermeneutics (pp. 208-226). Harvester Wheatsheaf.

Foucault, M. (1995). Discipline and punish: The birth of the prison. Vintage Books.

Geertz, C. (1983). Local knowledge: Further essays in interpretive anthropology. Basic Books.

Gergen, K. J. (1991). The saturated self: Dilemmas of identity in contemporary life. Basic Books.

Gergen, K. J. (2009). Relational being: Beyond self and community. Oxford University Pres

Habermas, T., \& Bluck, S. (2000). Getting a life: The emergence of the life story in adolescence. Psychological Bulletin, 126(5), 748-769. https://doi.org/10.1037/0033-2909.126.5.748

Harre, R. (1998). The singular self: An introduction to the psychology of personhood. SAGE Publications Ltd.

Hermans, H. J. M. (1996a). Voicing the self: From information processing to dialogical interchange. Psychological Bulletin, 119(1), 31-50.

https://doi.org/10.1037/0033-2909.119.1.31

Hermans, H. J. M. (1996b). Opposites in a dialogical self: Constructs as characters. Journal of Constructivist Psychology, 9(1), 1-26. https://doi.org/10.1080/10720539608404649

Hermans, H. J. M. (2002). The dialogical self as a society of mind: Introduction. Theory \& Psychology, 12(2), 147-160. https://doi.org/10.1177/0959354302122001

Hermans, H. J. M. (2003). The construction and reconstruction of a dialogical self. Journal of Constructivist Psychology, 16(2), 89-130. https://doi.org/10.1080/10720530390117902

Hermans, H. J. M., \& Hermans-Konopka, A. (2010). Dialogical self theory: Posiotioning and counter- positioning in a globalizing society. Cambridge University Press.

Hermans, H. J. M., \& Kempen, H. J. G. (1993). The dialogical self: Meaning as movement. Academic Press.

Hinkle, D. N. (1965). The change of personal constructs from the viewpoint of a theory of construct implications [Unpublished doctoral dissertation]. Ohio State University.

James, W. (1890). The principles of psychology (Vol. 1). Macmillan.

Kelly, G. A. (1955). The psychology of personal constructs. Norton. 
Kelly, G. A. (1969). The psychotherapeutic relationship. In D. Maher (Ed.), Clinical psychology and personality: The selected papers of George Kelly (pp. 216-223). John Wiley \& Sons.

Kincheloe, J. L. (2001). Describing the bricolage: Conceptualizing a new rigor in qualitative research. Qualitative Inquiry, 7(6), 679-692. https://doi.org/10.1177/107780040100700601

Kincheloe, J. L. (2005). On to the next level: Continuing the conceptualization of the bricolage. Qualitative Inquiry, 11(3), 323-350. https://doi.org/10.1177/1077800405275056

Locke, J. (1690). /1975). An essay concerning human understanding. Oxford University Press.

Mair, M. (1977). The community of self. In D. Bannister (Ed.), New perspectives in personal construct theory (pp. 125-149). Academic Press.

Mayring, P. (2000). Qualitative content analysis. Forum Qualitative Sozialforschung/Forum:

Qualitative Social Research, 1(2), Art. 20. htt. http://nbn-resolving.de/um:nbn:de:0114$\underline{\text { fqs0002204 }}$

McAdams, D. P. (1985). Power, intimacy, and the life story: Personological inquiries into identity. Guilford Press.

McAdams, D. P. (2001). The psychology of life stories. Review of General Psychology, 5(2), 100-122. https://doi.org/10.1037/1089-2680.5.2.100

McAdams, D. P. (2006). The problem of narrative coherence. Journal of Constructivist Psychology, 19(2), 109-125. https://doi.org/10.1080/10720530500508720

Procter, H. G. (1981). Family construct psychology: An approach to understanding and treating families. In S. Walrond-Skinner (Ed.), Developments in family therapy (pp. 350-366).

Routledge \& Kegan Paul.

Procter, H. G. (1996). The family construct system. In D. Kalekin-Fishman \& B. Walker (Eds.), The structure of group realities: Culture and society in the light of personal construct theory (pp.161-180). Krieger.

Procter, H. G. (2014). Qualitative grids, the relationality corollary and the levels of interpersonal construing. Journal of Constructivist Psychology, 27(4), 243-262. https://doi.org/10.1080/10720537.2013.820655

Raggatt, P. T. F. (2000). Mapping the dialogical self: Towards a rationale and method of assessment. European Journal of Personality, 14(1), 65-90.

https://doi.org/10.1002/(SICI)1099-0984(200001/02)14:1<65::AID-PER351>3.0.CO;2-D

Raskin, J. D. (2016). Personal construct psychology in relation to an integrative constructivism. In D. A. Winter \& N. Reed (Eds.), The Wiley handbook of personal construct psychology (pp. 34-44). John Wiley \& Sons.

Sampson, E. E. (1985). The decentralization of identity: Toward a revised concept of personal and social order. American Psychologist, 40(11), 1203-1211. https://doi.org/10.1037/0003$\underline{\text { 066X.40.11.1203 }}$ 
Shavelson, R., \& Bolus, R. (1982). Self-concept: The interplay of theory and methods. Journal of Educational Psychology, 74(1), 3-17. https://doi.org/10.1037/0022-0663.74.1.3

Shotter, J. (1989). Social accountability and the social construction of "You". In J. Shotter \& K. J. Gergen (Eds.), Texts of identity (pp. 133-151). SAGE Publications.

Shotter, J. (1993). Conversational realities: Constructing life through language. SAGE Publications.

Stern, W. (1938). General psychology from the personalistic standpoint. Macmillan.

Stojnov, D. (1996). Kelly's theory of ethics: Hidden, mislaid, or misleading? Journal of Constructivist Psychology, 9(3), 185-199. https://doi.org/10.1080/10720539608404664

Stojnov, D. (2005). Od psihologije li_cnosti ka psihologiji osoba [From psychology of personality towards psychology of person]. Institut za pedagoška istraživanja.

Taylor, C. (1989). Sources of the self: The making of the modern identity. Harvard University Press.

Volo_sinov, V. N. (1973). Marxism and the philosophy of language. Seminar Press.

Vygotsky, L. S. (1978). Mind in society. Harvard University Press.

Walker, B. M., \& Crittenden, N. (2012). The use of laddering: Techniques, applications and problems. In P. Caputi, L. L. Viney, B. M. Walker, \& N. Crittenden (Eds.), Personal construct methodology (pp. 71-88). Wiley-Blackwell.

Willig, K. (2008). Introducing qualitative research in psychology. Open University Press. 